\title{
INTEGRATING ANTHROPOMETRY APPROACH AND KANSEI ENGINEERING IN THE DESIGN OF CHILDREN SHOE
}

\section{Annisa Dwi NOVIANI, Ari WIDYANTI**}

Department of Industrial Engineering, Bandung Institute of Technology (ITB), Indonesia, Labtek 3 Ganesa 10 Bandung 40132 Indonesia, email: widyanti@mail.ti.itb.ac.id

\section{INTEGRATING ANTHROPOMETRY APPROACH AND KANSEI ENGINEERING IN THE DESIGN OF CHILDREN SHOE}

ABSTRACT. Shoes play an important role in human life. For children in particular, shoes also support the development of their feet. This study is aimed to integrate anthropometric approach with Kansei Engineering in designing shoes for Indonesian children. Eighteen dimensions of foot anthropometry for 331 Indonesian Sundanese children ages 6-10 were measured and presented, a shoe size chart for Indonesian children is proposed as well. Moreover, Kansei Engineering was applied to capture consumers' 'emotion' toward children's shoe design and was evaluated both for Indonesian parents and children. The result shows that emotion related to children's shoe design are comfort and appearance. The implication of the results is further discussed.

KEY WORDS: Indonesian, children, shoe, anthropometry, Kansei, engineering

INTEGRAREA ABORDĂRII ANTROPOMETRICE ŞI A INGINERIEI KANSEI ÎN PROIECTAREA ÎNCĂLTY̆MINTEI PENTRU COPII

REZUMAT. Încălţămintea joacă un rol important în viaţa oamenilor. În special în cazul copiilor, încălţămintea susţine dezvoltarea picioarelor acestora. Acest studiu are ca scop integrarea abordării antropometrice şi ingineria Kansei în proiectarea încălţămintei pentru copiii indonezieni. S-au măsurat optsprezece dimensiuni antropometrice ale piciorului la 331 de copii sundanezi din Indonezia cu vârstele cuprinse între 6 şi 10 ani şi s-a propus o diagramă a dimensiunilor încălțămintei pentru copii indonezieni. În plus, s-a aplicat ingineria Kansei pentru a capta „impresia” consumatorilor faţă de designul încălţămintei pentru copii, evaluând atât percepţia părinţilor, cât şi a copiilor din Indonezia. Rezultatul arată că impresiile legate de designul încălţ̧ămintei pentru copii sunt confortul şi aspectul. Se discută implicaţiile rezultatelor obţinute.

CUVINTE CHEIE: indonezieni, copii, încălţăminte, antropometrie, Kansei, inginerie

\section{L'INTEGRATION DE L'APPROCHE ANTHROPOMETRIQUE ET L'INGENIERIE KANSEI DANS LA CONCEPTION DES CHAUSSURES POUR LES} ENFANTS

RÉSUMÉ. Les chaussures jouent un rôle important dans la vie humaine. Pour les enfants en particulier, les chaussures favorisent également le développement de leurs pieds. Cette étude vise à intégrer l'approche anthropométrique et l'ingénierie Kansei à la conception de chaussures pour les enfants indonésiens. On a mesuré 18 dimensions anthropométriques du pied chez 331 enfants indonésiens sundanais âgés de 6 à 10 ans, et on a proposé un tableau des pointures des chaussures pour enfants indonésiens. De plus, l'ingénierie Kansei a été utilisé pour capturer "l'émotion " des consommateurs à l'égard de la conception de chaussures pour les enfants et l'on a évalué à la fois pour les parents et les enfants indonésiens. Le résultat montre que les émotions liées à la conception des chaussures pour les enfants sont le confort et l'apparence. L'implication des résultats est discutée plus en détail.

MOTS CLÉS : indonésien, enfants, chaussure, anthropométrie, Kansei, ingénierie

\footnotetext{
* Correspondence to: Ari WIDYANTI, Department of Industrial Engineering, Bandung Institute of Technology (ITB), Indonesia, Labtek 3 Ganesa 10 Bandung 40132 Indonesia, email: widyanti@mail.ti.itb.ac.id
} 


\section{INTRODUCTION}

Shoes play a crucial role in human activity. Originally, shoes were worn for human protection from the environment, particularly from injury and infection [1]. However, shoes have evolved to be a form of social status, and more recently have even emerged as a fashion trend. Later, shoes also have been developed as a part of medicine, known as the corrective shoe [1]. It is not surprising, therefore, that research in shoes has been conducted for decades, for example in relation with aspects of the foot $[2,3]$, design elements of the shoes $[4,5]$ and technology of the shoes' design $[6,7]$.

In designing shoes, some considerations are applied such as the foot shape and dimensions, manufacturability and consumer preference [8]. Foot shape and dimensions in particular are closely related to shoe size. Shoe size is crucial when the shoe is used to support the foot in its physiological function and development $[1,9]$. Failure to consider foot dimensions leads to negative consequences [10] such as foot problems and pathologies in childhood and adulthood $[1,11]$ as well as strain in foot muscles and tendons [12].

Shoe size is an important feature of the shoe, not only to avoid negative consequences of an ill-fitting shoe, but also to satisfy a wide range of consumers with a vast choice of footwear sizes applicable to multiple individual and group needs [13]. Thus, research in shoe size system or shoe size standards have been often conducted $[3,14]$.

In most shoe systems, shoe sizes are predetermined by the last, a mechanical form of a human foot that have been made from various materials, such as hardwoods and high-density plastics [15]. It is usually used by shoe makers or shoe designers. The shoe last corresponds with foot dimensions through all parts of the last such as foot length, ball, instep, and heel [16]. Therefore, the same foot length can vary in regards to the position of the ball-of-foot, instep height, or heel width which are important features for a well-fitting shoe. In general, within one size, values for these dimensions are set to be fixed.

Several methods have been used in determining shoe size. One commonly used method in shoe size system is the mondopoint system. This method/system is based on the mean foot length and width for which the shoe is suitable (in millimeters). This method is used as a base of ISO 9407:1991 [17]. The mondopoint has an advantage for better fit than most other systems since it takes the foot width into account. The mondopoint has been applied in the USA shoe size system and generally most army shoes. Other shoe size systems are available and have been used in different countries. For examples, shoe sizing in the United Kingdom (British size) is based on the length of the last and the formula is [ $(3 \times$ last length in inch $)-12]$ or [ $(3 \times$ heel to toe length in inch) - 10]. The Continental European system, used in most continental European countries, considers the length of the last for the shoe size with the formula being $(3 / 2 \times$ last length in $\mathrm{cm})$ or $(3 / 2 \times$ foot length in $\mathrm{cm}(+1.5))$ [15].

Children's shoes have been gaining attention for years in several countries (e.g., in Malaysia [18] and Srilangka [19]. It should be underlined that most shoe size systems differentiate adult and children shoes. For children, shoes are not just used to protect the wearer from the environment nor for fashion. Children must wear proper shoe sizes according to their foot measurement and shape because ill-fitting shoes can influence the normal development of a maturing foot [11]. Parents who have children aged 5 and 6 years old reportedly also face problems in finding correct footwear sizes for their children [8].

As stated earlier, not only is the shoe size system important in the design of children's shoes, but also other aspects of design regarding the preference or perception of consumers are important as well [8]. The study of perception in shoe design is of great interest to designers. 
Perception will influence consumers when making decisions about the different types of shoes they purchase [20].

In general, several techniques can be used to translate consumer or user needs and preferences into product design characteristics [21]. The techniques include Quality Function Development (QFD) - which can be used to identify the relationship between consumer needs and engineering characteristics [22] and Kansei Engineering - which can be used to translate consumers' feelings and image for a product into design elements [23]. In other words, Kansei Engineering is a method of consumer-oriented product development based on the consumer mind.

Indonesia is a developing country with a large number of children which make Indonesians a potential market for children's shoes. Unfortunately, the Indonesian children shoe market is dominated by imported shoes. As a matter of fact, the number of imported shoes in Indonesia is increasing yearly [24]. Regrettably, most Indonesian footwear manufacturers lack adequate knowledge on the requirements for designing and producing footwear. Moreover, children's shoes in the Indonesian market are based on foreign sizing such as US and UK standard sizes [20] which are not suitable for Indonesian children. This condition is similar to that of children clothing in Indonesia [25]. Coupled with the increase of the middle class population in Indonesia, parents' attention to children's shoes is elevating. Therefore, more attention should be given to the shoe design particularly in relation with parents' perception about shoes that suit the environment and the purpose.

The aim of this study is to integrate anthropometric approach with Kansei Engineering in the design of Indonesian children's shoes. Anthropometric approach is crucial in determining shoe size system whereas Kansei Engineering is important in capturing the feelings and preferences of shoes for
Indonesian children and parents. The integration of anthropometry and Kansei Engineering in the design of Indonesian children's shoes will ensure the creation of shoes that are functional as wellfitting to the current trends and lifestyle of the target market.

\section{EXPERIMENTAL}

\section{Anthropometry Measures}

\section{Subjects}

Three hundred and thirty-one Sundanese Indonesian elementary school students, aged 6 - 10 years old, were voluntarily involved in this study. They were recruited from three elementary schools in the West Java area. Permits were obtained from the school principals with a prior request letter from the Laboratory for Work System Design and Ergonomics of Bandung Institute of Technology. Ethical guidelines have been followed and measurement procedures have been approved by an ethical committee. The participants were instructed to be barefooted during the foot measurement.

\section{Procedure}

Eighteen foot anthropometry data were measured: 1) foot length, 2) arch length, 3) heel to medial malleolus, 4) heel to lateral malleolus, 5) heel to $5^{\text {th }}$ toe, 6) foot width, 7) heel width, 8) bimalleolar width, 9) mid-foot width, 10) medial malleolus height, 11) lateral malleolus height, 12 ) height at $50 \%$ foot length, 13) ball girth, 14) instep girth, 15) long heel girth, 16) short heel girth, 17) ankle girth and 18) waist girth. The anchor point of measure for each dimension can be seen in Figure 1. The eighteen foot anthropometry dimensions were chosen since these dimensions are the most commonly used in footwear design. 


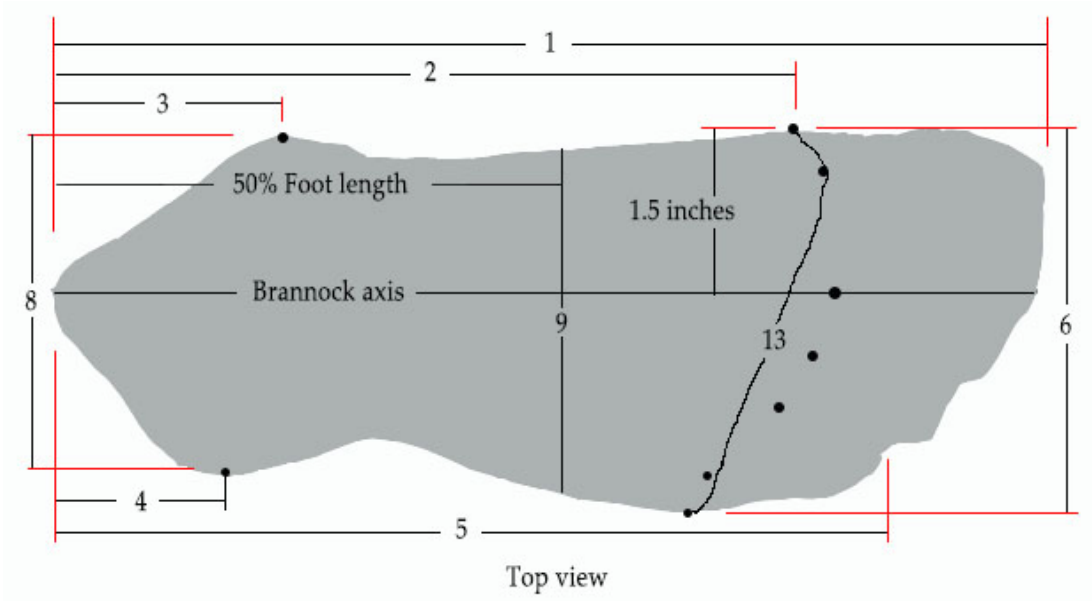

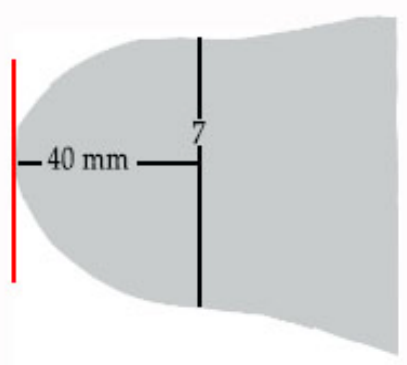

Bottom view

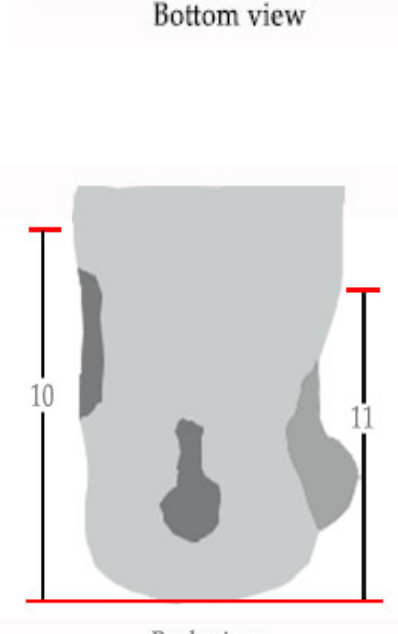

Back view

try

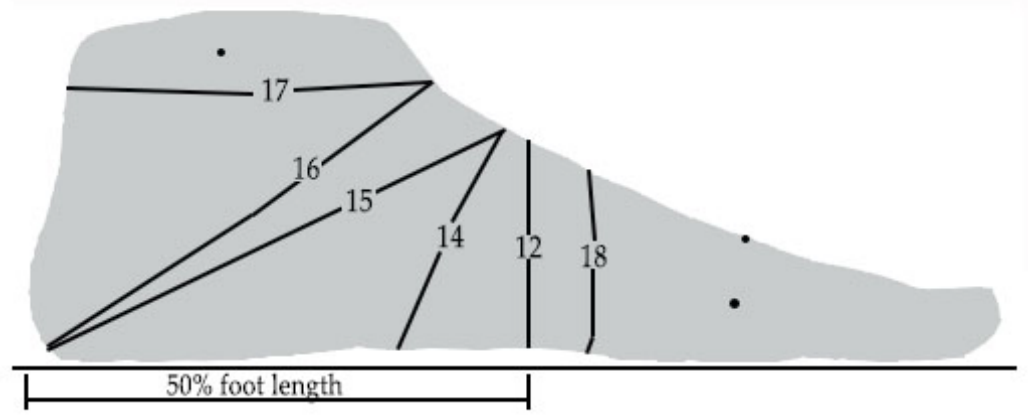

Side view
The measurement was conducted using a manual method due to restriction on research budget and technical constraint. Subjects were barefooted during measurement with a time measurement for each subject of around 10 minutes. First, participants were instructed to stand on a piece of white paper with a landmark of heel touching the background wall. A pattern of the foot was drawn out on the paper using a pencil based on the foot contour. This pattern was used as a base to measure all length of foot dimensions. In addition, the calliper was used to measure height dimensions and measuring tape was used to measure girth.

The measurement was conducted by 10 student research assistants who received prior knowledge and training regarding the foot measurement. The training was intended to avoid intra-observer error (i.e., error when repeated measurements were taken by the same observer [26]) and inter-observer error (i.e., error when repeated measurements were taken by different observers $[25,27,28])$. To ensure correct measurements and valid data were obtained, authors performed random checks during measurement.

\section{Kansei Engineering}

Kansei Engineering is used to capture consumers' feelings and images towards a product and used it in design elements. The steps in Kansei Engineering used in this study are explained as follows. First, kansei words for children's shoes were generated based on literature study and consumer perception. The kansei words were separated for boys and girls' shoes. 53 subjects consisting of 22 parents with 6-10 year old children (all female) and 31 children (14 boys and 17 girls) participated voluntarily in the study by filling out a questionnaire with one only question "what are the words or sentences that can describe boys' and girls' shoes". As stated by Nagamachi [23], kansei word identification is stopped when no new kansei words are identified. 
Second, kansei words were restructured using confirmatory study and expert opinion. In the confirmatory study, the previously identified kansei words proposed in the first questionnaire and another sample of participants $(n=30,20$ female) were asked their agreement upon the identified kansei words in relation with children's shoes. Next, expert opinion from one linguistic expert was obtained to avoid bias or duplications in resulted kansei words from the confirmatory study.

Third, a second questionnaire was developed to observe the importance of the restructured kansei words with a Likert scale ranging from 1 (not important at all) to 5 (very important). Six samples of favorite children's shoe products were used as base of evaluation. The samples of the product can be seen in Figure 2 .
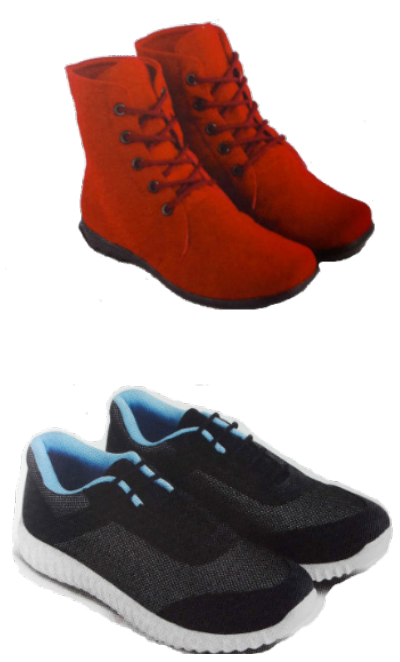
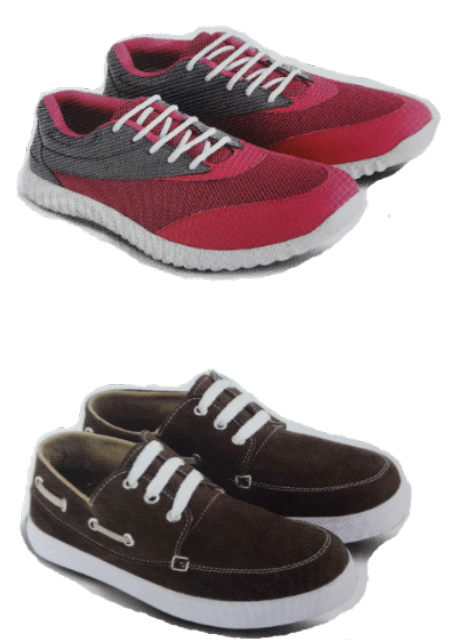
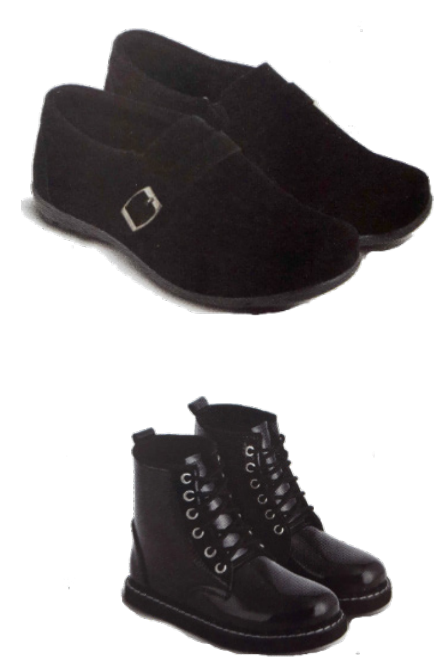

Figure 2. Example of shoe product to be evaluated, upper for girls' shoe and lower for boys' shoe

Participants were asked to give a rating for each sample of product based on the kansei words with scale ranging from 1 (very bad) to 5 (very good). 112 participants were involved in completing the second questionnaire. Higher structurization of kansei words was conducted through Principal Component Analysis on the final score of the multiplier of the importance of the attributes and ratings of each sample product.
Lastly, a synthesis of product attributes based on Kansei Engineering was conducted through an interview with children's shoe manufacturer.

\section{RESULTS AND DISCUSSIONS}

\section{Foot anthropometry}

Foot anthropometry data of Indonesian children can be seen in Table 1.

Table 1: Foot anthropometry of Indonesian children (in $\mathrm{cm}$ )

\begin{tabular}{|c|c|c|c|c|c|c|c|c|c|}
\hline \multirow{2}{*}{ No } & \multirow{2}{*}{$\begin{array}{l}\text { Foot anthropometry } \\
\text { dimensions }\end{array}$} & \multicolumn{4}{|c|}{ Boys } & \multicolumn{4}{|c|}{ Girls } \\
\hline & & Mean & SD & P5 & P95 & Mean & SD & P5 & P95 \\
\hline 1 & Foot length & 19.70 & 1.65 & 17.19 & 22.41 & 19.49 & 1.43 & 17.30 & 22.00 \\
\hline 2 & Arch length & 14.18 & 1.31 & 12.10 & 16.20 & 14.06 & 1.24 & 12.10 & 16.20 \\
\hline 3 & Heel to medial malleolus & 4.54 & .83 & 3.20 & 5.90 & 4.40 & .78 & 3.10 & 5.70 \\
\hline 4 & Heel to lateral malleolus & 3.76 & .87 & 2.30 & 5.20 & 3.70 & .79 & 2.30 & 5.10 \\
\hline 5 & Heel to 5 th toe & 16.21 & 1.31 & 14.05 & 18.26 & 16.10 & 1.07 & 14.40 & 17.70 \\
\hline 6 & Foot width & 8.05 & .48 & 7.20 & 8.90 & 8.10 & .53 & 7.20 & 9.00 \\
\hline 7 & Heel width & 5.02 & .50 & 4.25 & 6.00 & 4.97 & .48 & 4.10 & 5.90 \\
\hline 8 & Bimalleolar width & 6.35 & .71 & 5.15 & 7.56 & 6.29 & .71 & 5.20 & 7.60 \\
\hline
\end{tabular}




\begin{tabular}{llllllllll}
9 & Mid-foot width & 6.41 & .68 & 5.22 & 7.56 & 6.35 & .62 & 5.30 & 7.40 \\
10 & Medial malleolus height & 5.52 & .49 & 4.76 & 6.36 & 5.42 & .55 & 4.50 & 6.30 \\
11 & Lateral malleolus height & 4.86 & .93 & 3.07 & 6.20 & 4.78 & .98 & 3.20 & 6.30 \\
12 & Height at 50\% foot length & 3.77 & .36 & 3.20 & 4.40 & 3.84 & .37 & 3.20 & 4.40 \\
13 & Ball girth & 19.22 & 1.95 & 16.34 & 22.50 & 19.08 & 1.71 & 16.50 & 22.00 \\
14 & Instep girth & 20.48 & 2.27 & 17.35 & 24.72 & 20.84 & 2.40 & 17.50 & 25.30 \\
15 & Long heel girth & 25.78 & 2.78 & 21.78 & 30.61 & 25.67 & 2.57 & 22.00 & 30.20 \\
16 & Short heel girth & 24.80 & 2.39 & 21.50 & 28.78 & 24.52 & 2.11 & 21.50 & 28.50 \\
17 & Ankle girth & 18.37 & 2.03 & 15.59 & 22.11 & 18.48 & 1.93 & 15.50 & 21.80 \\
18 & Waist girth & 18.48 & 1.48 & 16.00 & 20.80 & 18.36 & 1.24 & 16.50 & 20.50 \\
\hline
\end{tabular}

Principal Component Analysis (PCA) was applied to observe the foot anthropometry dimensions that correlate with the principal dimensions of shoe size (i.e., foot length). The result of the PCA can be seen in Table 2 .

Table 2: Principal Component Analysis of foot anthropometry dimensions

\begin{tabular}{lccc}
\hline \multirow{2}{*}{ Foot anthropometry data } & \multicolumn{3}{c}{ Component } \\
& 1 & 2 & 3 \\
\hline Foot length & .816 & & \\
Arch length & .812 & & \\
Heel to 5th toe & .767 & & \\
Bimalleolar width & & .809 & \\
Height at 50\% foot length & & & .735 \\
Ball girth & .874 & & \\
Instep girth & .791 & & \\
Long heel girth & .800 & \\
Short heel girth & .881 & \\
\hline
\end{tabular}

It can be seen that the foot length is in a similar component with arch length, heel to $5^{\text {th }}$ toe, ball girth, instep girth, long heel girth and short heel girth. In addition, it should be underlined that the shoe size standard most commonly found in Indonesia is European Union (EU) standard. Incorporating the EU shoe size system and the result of the PCA analysis above, the suggested shoe size chart, which include the most commonly measured anthropometry data, are similar with the PCA result (i.e., foot length, foot width, toe length). The values of foot length, foot width and toe length are calculated from the regression analysis based on the foot length. The proposed shoe size chart can be seen in Table 3 .

Table 3: Shoe size chart and the corresponding dimensions for Indonesian children

\begin{tabular}{ccccc}
\hline \multirow{2}{*}{ Euro shoe size } & \multicolumn{4}{c}{ Corresponding foot dimensions for Indonesian children (in cm) } \\
& Length & Width & Ball girth & Toe length \\
\hline 15.5 & 8.3 & 5.1 & 11.4 & 4.4 \\
16 & 8.9 & 5.3 & 11.7 & 5.3 \\
16.5 & 9.2 & 5.5 & 11.9 & 5.7 \\
17 & 9.5 & 5.6 & 12.1 & 6.1 \\
17.5 & 10.2 & 5.9 & 12.5 & 7.1
\end{tabular}




\begin{tabular}{|c|c|c|c|c|}
\hline \multirow{2}{*}{ Euro shoe size } & \multicolumn{4}{|c|}{ Corresponding foot dimensions for Indonesian children (in $\mathrm{cm}$ ) } \\
\hline & Length & Width & Ball girth & Toe length \\
\hline 18 & 10.5 & 6.0 & 12.7 & 7.5 \\
\hline 18.5 & 10.8 & 6.1 & 12.9 & 7.9 \\
\hline 19 & 11.4 & 6.3 & 13.3 & 8.7 \\
\hline 19.5 & 11.7 & 6.4 & 13.5 & 9.1 \\
\hline 20 & 12.1 & 6.5 & 13.7 & 9.6 \\
\hline 21 & 12.7 & 6.7 & 14.1 & 10.3 \\
\hline 22 & 13 & 6.8 & 14.3 & 10.6 \\
\hline 22.5 & 13.3 & 6.9 & 14.5 & 11.0 \\
\hline 23 & 14 & 7.1 & 15.0 & 11.7 \\
\hline 23.5 & 14.3 & 7.2 & 15.2 & 12.0 \\
\hline 24 & 14.6 & 7.2 & 15.4 & 12.4 \\
\hline 24.5 & 15.2 & 7.4 & 15.8 & 12.9 \\
\hline 25 & 15.6 & 7.5 & 16.1 & 13.3 \\
\hline 26 & 15.9 & 7.5 & 16.3 & 13.6 \\
\hline 27 & 16.5 & 7.7 & 16.8 & 14.1 \\
\hline 27.5 & 16.8 & 7.7 & 17.0 & 14.3 \\
\hline 28 & 17.1 & 7.8 & 17.2 & 14.6 \\
\hline 29 & 17.8 & 7.9 & 17.7 & 15.1 \\
\hline 30 & 18.1 & 7.9 & 18.0 & 15.3 \\
\hline 30.5 & 18.4 & 8.0 & 18.2 & 15.5 \\
\hline 31 & 19.1 & 8.1 & 18.7 & 16.0 \\
\hline 31.5 & 19.4 & 8.1 & 19.0 & 16.2 \\
\hline 32 & 19.7 & 8.1 & 19.2 & 16.3 \\
\hline 33 & 20.3 & 8.2 & 19.7 & 16.7 \\
\hline 33 & 20.6 & 8.2 & 19.9 & 16.8 \\
\hline 34 & 21 & 8.2 & 20.2 & 17.0 \\
\hline 34 & 21.6 & 8.3 & 20.7 & 17.2 \\
\hline 35 & 21.9 & 8.3 & 21.0 & 17.4 \\
\hline 36 & 22.2 & 8.3 & 21.2 & 17.5 \\
\hline 36 & 22.9 & 8.3 & 21.8 & 17.7 \\
\hline 37 & 23.2 & 8.3 & 22.1 & 17.8 \\
\hline 37 & 23.5 & 8.3 & 22.3 & 17.9 \\
\hline
\end{tabular}

\section{Kansei Engineering}

In the first step - kansei words identification - for parent participants, no more kansei words were found after the $19^{\text {th }}$ participant, indicating a sufficient number of participants for kansei word identification. In total, 114 and 107 kansei words for both boys and girls' shoes were obtained from all participants - both parents and children - in addition to literature study as well. Examples of the identified kansei words include "simple", "casual" and "comfort".
Restructurization of kansei words using confirmatory study and expert opinion resulted in 21 groups and 18 groups of kansei for girls and boys' shoe respectively. Higher kansei restructrurization conducted using PCA with varimax rotation resulted in 4 dimensions for girls' shoes and 3 dimensions for boys' shoes. For those dimensions, the $1^{\text {st }}$ dimension for girls and boys' shoes is related with the comfort aspect of the shoe. Whereas the $2^{\text {nd }}, 3^{\text {rd }}$, and $4^{\text {th }}$ dimensions for girls' shoes and $2^{\text {nd }}$ and $3^{\text {rd }}$ dimensions for boys' shoes are related with the 
appearance of the shoe. The dimensions and the related variable can be seen in Table 4.

Table 4: Result of kansei engineering in Indonesian children's shoes

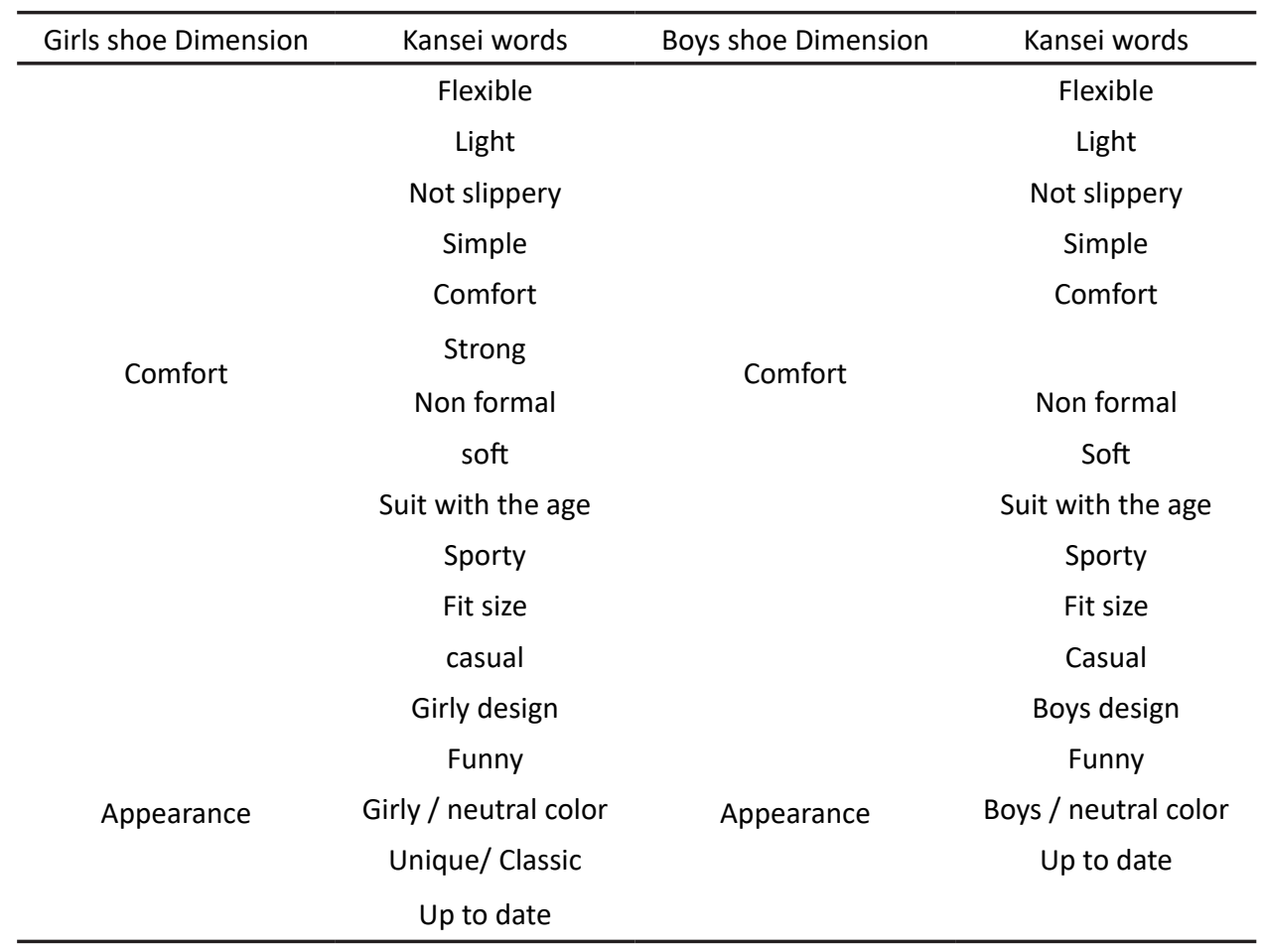

Synthesis of the dimensions to find Indonesian children's shoe manufacturer and significant attributes of children's shoes design can be seen in Table 5 and Figure 3.

was conducted through an interview with

Table 5: Synthesis of kansei words into shoe attribute

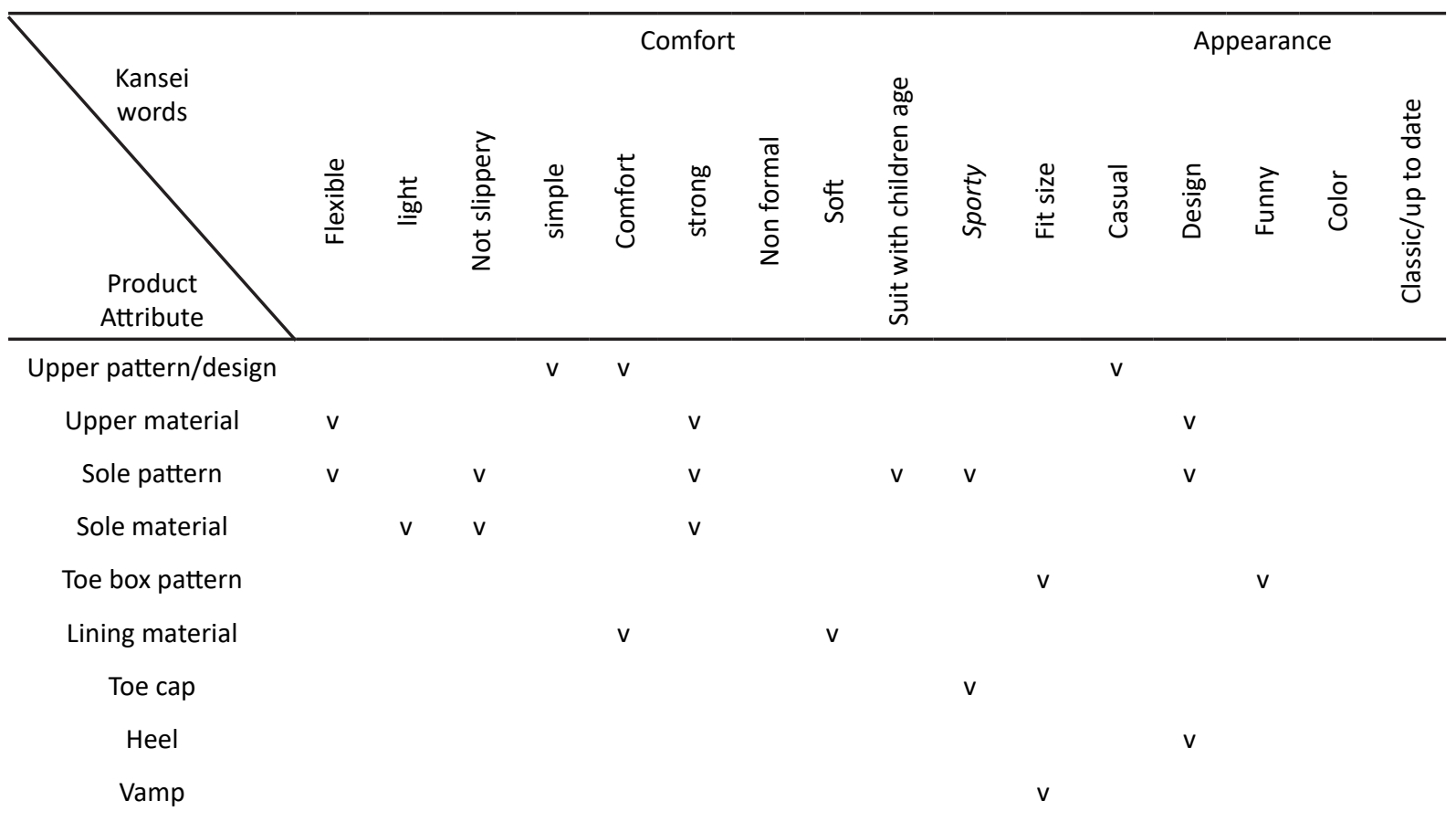




\begin{tabular}{|c|c|c|c|c|c|c|c|c|c|c|c|c|}
\hline Color & & & & & v & & & v & & v & v & v \\
\hline Accessories & & v & & & & v & v & v & & v & & v \\
\hline Model & v & & v & & v & v & & & v & v & & v \\
\hline Shoe tongue & & $\mathrm{v}$ & & v & & $\mathrm{v}$ & & & & & & \\
\hline
\end{tabular}

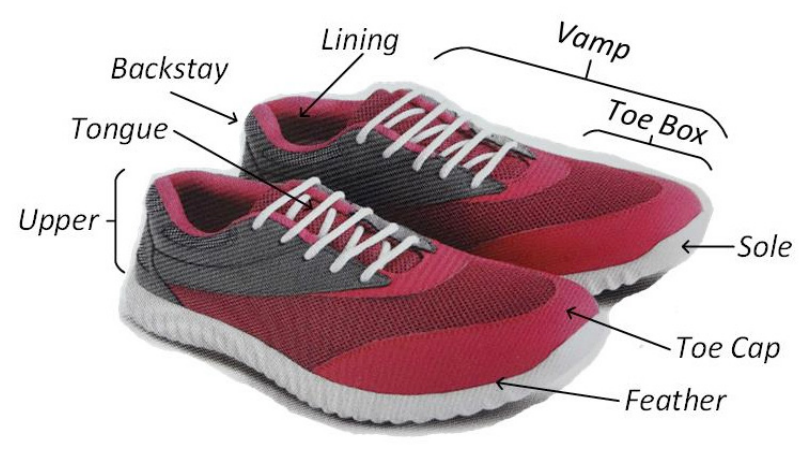

Figure 3. Attribute of the children shoe

The aim of this study is to integrate anthropometry and Kansei Engineering in the design of Indonesian children's shoes. From the view of anthropometry data, there are no significant differences between boys and girls in Indonesian children's foot anthropometry data. Although it is well established that genderspecific differences in foot shape exist in adults (see [29] for an example), some research did not discover the differences in their findings [30]. It should be noted that the gender differences in children's foot anthropometry is observed after puberty and may be a contributing factor for no anthropometric variations between the boys and the girls in this study. The result of this present study also supports race difference in anthropometry data [9], in which the Indonesian foot anthropometry data is smaller than Caucasian ones (for example Spanish children foot anthropometry data [31]).

The result of PCA shows that foot length highly correlates with arch length, heel to $5^{\text {th }}$ toe, ball girth, instep girth, long heel girth and short heel girth. This result supports previous studies in corresponding foot length with other dimensions of foot anthropometry such as ball girth [17] and toe length [32]. It should be underlined, however, that the differences in the corresponding dimensions of foot length varies due to the different numbers of data and the different foot structures among samples of these studies [33].

The importance of suitability of shoe size with foot development in children have been realized by Indonesian parents [20]. The negative consequences of huge variation in shoe size system in Indonesian children's shoes have been underlined by the shoe manufacturer and consumers as well. Therefore, study about Indonesian children's shoe size is of utmost importance. In this present study, instead of developing a new shoe size system for Indonesian children, we prefer completing the shoe size chart available in the market. The consideration for the completion of the chart is since the effort to develop a new standard of shoe size system in Indonesia has failed [34]. The additional anthropometry references (i.e., ball girth) is due to consideration of the different structure of foot [33]. In addition, a small interview with a shoe manufacturer reveals the difficulties of the shoe manufacturer in adapting a possible new shoe size system.

Kansei Engineering applied for Indonesian children's shoes in this present study shows that Indonesian consumer preference for children's shoe design falls in the category of comfort and appearance. The "comfort" and "appearance" 
were synthesized into the attributes of the product such as sole and vamp, which give guidance for the shoe manufacturer in the design process of Indonesian children's shoes. As stated by Penkala et al. [8], shoe-fitting practices were affected not only by the available shoe size, but also by shoe style (i.e., related with comfort and appearance).

Kansei Engineering used in this study has some advantages. Kansei Engineering establishes a suitable framework for working with symbolic attributes and user perceptions, expressed in their own words. It also establishes a framework for quantifying the relationships between design characteristics and emotional responses [23, 35]. These contributions are very meaningful in areas such as shoe design, where emotional impressions can explain a significant part of the variance associated with the purchase decision. Two levels of kansei word restructurization were applied, instead of only one level of kansei word restructurization, since the two levels provide less number of kansei words per groups and in return gives more focused result.

This study has several limitations worth noting. First, the sample of participants in anthropometry measurement is limited to Sundanese children only. Considering the ethnic differences in Indonesian anthropometry data [27], further study covering other ethnicity in Indonesia is needed. Second, the foot anthropometry measures were conducted using manual measurement. Although the validity of such measures is often questionable compared to advanced measurements such as using foot scanner, due to restriction of research budget and technical limitation, the manual measure was used. Furthermore, since the observers received prior training in relation with the measurement, it can be argued that inter and intra-observer error in this study are minimized. However, further study comparing result of manual and foot scanner measurements should also be conducted. Third, the participants of Kansei Engineering approach are limited to parents and children in Bandung as a representative of big cities in Indonesia. Further research involving participants from small cities or rural areas is suggested.

\section{CONCLUSIONS}

In conclusion, the present study gives valuable contribution in the initial step of providing foot anthropometry data of Indonesian children as well as a rigorous children shoe size chart in Indonesia. Not only related with the shoe size system, this study also shows the preferences of Indonesian consumers in relation with children's shoes. The result of this present study will help Indonesian children's shoe manufacturers to design marketable children's shoe design. For consumers, result of this present study could minimize error in choosing shoe sizes as well as give more choices in children's shoe design. It should be underlined that shoes of the future should be designed to support function and protection while retaining comfort and appearance.

\section{REFERENCES}

1. Staheli, L.T., Shoes for children: A review, Pediatrics, 1991, 88, 2, $371-375$.

2. Makiko, K., Inter-generation differences in foot morphology: aging or secular change? J Hum Ergol, 2003, 32, 1, 23-48.

3. Nakayama, K., Abe, K., Nagai, K., Oi, K., Oi, $\mathrm{H}$. , Establishing reference sizes for the rear portion of the foot for use in designing lasts for women's shoes, Footwear Sci, 2016, 3339, https://doi.org/10.1080/19424280.2016. 1260644.

4. Bita, T.S., Raffaele, D.A., A CAD system for evaluating footwear fit, International Conference on Multimedia, Computer Graphics and Broadcasting, 2009, 60, 1-7, https://doi.org/10.1007/978-3-642-105128_1.

5. Xiong, S., Goonetilleke, R.S., Witana, C.P., Lee Au, E.Y. Modelling foot height and foot shape-related dimensions, Ergon, 2008, 51, 8, 1271-1289, https://doi. org/10.1080/00140130801996147.

6. Masaaki, M., Makiko, K., Masako, D., Analysis of 3-D human foot forms using the free form deformation method and its application in grading shoe lasts, Ergon, 2000, 43, 9, 1301-1313, https://doi. org/10.1080/001401300421752. 
7. Telfer, S., Woodburn, J., The use of 3D surface scanning for the measurement and assessment of the human foot, $J$ Foot Ankle Res, 2010, 3, 19, https://doi. org/10.1186/1757-1146-3-19.

8. Penkala, S., Harris, L., Hunt, A., Naughton, G., Children's shoe styles and parent decisions to fit shoes with store staf decisions to fit shoes with store staff assistance, I Foot Ankle Res, 2011, 4(Suppl 1), 035, https://doi. org/10.1186/1757-1146-4-S1-035.

9. Hawes, M.R., Sovak, D., Miyashita, M., Kang, S.J., Yoshihuku, Y., Tanaka, S., Ethnic differences in forefoot shape and the determination of shoe comfort, Ergon, 1994, 37, 1, 187-196, https://doi. org/10.1080/00140139408963637.

10.Mauch, M., Grau, S., Krauss, I., Maiwald, C., Horstmann, T., A new approach to children's footwear based on foot type classification, Ergon, 2009, 52, 8, 999-1008, https://doi. org/10.1080/00140130902803549.

11.Echarri, J.J., Forriol, F., The development in footprint morphology in 1851 Congolese children from urban and rural areas, and the relationship between this and wearing shoes, J Pediatr Orthop B, 2003, 12, 141-146, https:// doi.org/10.1097/01202412-20030300000012.

12.Luximon, A., Goonetilleke, R.S., Tsui, K.L., Foot land marking for footwear customization, Ergon, 2003, 46, 364-383, https://doi.org/10 $.1080 / 0014013021000045225$.

13.Ujevic, D., Hrzenjak, R., Croatian anthropometric system. Paper presented at First Congress of Croatian Scientists from Croatia and Abroad, Zegreb - Vukovar, November, 15-19, 2004.

14. Hinojo-Perez, J.J., Davia-Aracil, M., JimenoMorenilla, A., Sanchez-Romero, J.L., Automation of the shoe last grading process according to international sizing systems, Int J Adv Manuf Tech, 2016, 85, 1, 455-467, https://doi.org/10.1007/s00170-015-7947-8.

15.Luximon, A., Ma, X., Handbook of Footwear Design and Manufacture, Elsevier Science, 2013, https://doi. org/10.1533/9780857098795.
16. Rossi, W.A., Tennant, R., Professional shoe fitting, New York, NY: National Shoe Retailers Association, 1984.

17. International Standard. Shoes sizesmondopoint system of sizing and marking. ISO 9407, 1-3. 1991.

18.Bari, S.B., Othman, M., Salleh, N.M., Foot Anthropometry for Shoe Design among preschool Children in Malaysia, Pertanika $J$ Soc Sci Hum, 2010, 18, 1, 69-79.

19. Hettigamaa, I.S., Punchihewaa, H.K.G., Heenkendab, N.K., Ergonomic footwear for Sri Lankan primary schoolchildren: A review of the literature, Work, 2016, 55, 2, 285-295, https://doi.org/10.3233/WOR-162415.

20.Noviani, A.D., Anthropometry and kansei engineering approach in design of Indonesian children' shoe, Bachelor thesis, Bandung Institute of Technology, Indonesia, 2017.

21. Llinares, C., Page, A.F., Kano's model in Kansei Engineering to evaluate subjective real estate consumer preferences, Int J Ind Ergon, 2011, 41, 233-246, https://doi.org/10.1016/j. ergon.2011.01.011.

22.Cohen, L., Quality Function Deployment, How to Make QFD Work for You, Addison-Wesley, Massachusetts, 1995.

23. Nagamachi, M., Kansei Engineering: a new ergonomic consumer-oriented technology for product development, Int J Ind Ergon, 1995, 15, 3-11, https://doi.org/10.1016/01698141(94)00052-5.

24. Indonesian ministry of industry, 2016. Available at http://www.kemenperin.go.id/ artikel/6335/Sepatu-Impor-Kuasai-SeparuhPasar-Domestik. Accessed 20 June 2017.

25.Widyanti, A., Mahachandra, M., Soetisna, H.R., Sutalaksana, I.Z., Anthropometry of Indonesian Sundanese children and the development of clothing size system for Indonesian Sundanese children aged 6-10 years, Int J Ind Ergon, 2017, 61, 37-46, https:// doi.org/10.1016/j.ergon.2017.05.008.

26. Kouchi, M., Mochimaru, M., Tsuzuki, K., Yokoi, T., Random errors in anthropometry, J Hum Ergol, 1999, 25, 155-166. 
27.Widyanti, A., Susanti, L., Sutalaksana, I.Z., Muslim, K., Ethnic differences in Indonesian anthropometry data: Evidence from three different largest ethnic, Int J Ind Ergon, 2015, 47, 72-78, https://doi.org/10.1016/j.ergon.2015.02.008.

28.Sutalaksana, I.Z., Widyanti, A., Anthropometry approach in workplace redesign of Indonesian Sundanese roof tile industries, Int $J$ Ind Ergon, 2016, 53, 299-305, https://doi. org/10.1016/j.ergon.2016.03.002.

29.Wunderlich, R.E., Cavanagh, P.R., Gender differences in adult foot shape: implications for shoe design, Med Sci Sports Exerc, 2001, 33, 605 -611, https://doi. org/10.1097/00005768-200104000-00015.

30.Unger, H., Rosenbaum, D., Gender-specific differences of the foot during the first year of walking, FootAnkle Int, 2004, 582-587, https:// doi.org/10.1177/107110070402500812.

31.Delgado-Abellan, L., Aguado, X., JimenezOrmeno, E., Mecerreyes, L., Alegre, L.M., Foot morphology in Spanish school children according to sex and age, Ergon, 2014, 57, 5, 787-797, https://doi.org/10.1080/00140139 .2014.895055.

32.Luximon, A., Luximon, Y., Shoe-last design innovation for better shoe fitting, Comput Ind, 2009, 60, 621-628, https://doi.org/10.1016/j. compind.2009.05.015.
33. Mauch, M., Mickle, K.J., Munro, B.J., Dowling, A.B., Grau, S., Steele, J.R., Do the feet of German and Australian children differ in structure? Implication for children's shoe design, Ergon, 2008, 51, 527-539, https://doi. org/10.1080/00140130701660520.

34. Wiryodiningrat, S., Basuki, D.A., Standard for Indonesian shoe size (Standar acuan sepatu anak Indonesia), Jurnal Standardisasi, 2014, 14, 3 (In Indonesian).

35.Demirtas, E.A., Anagun, A.S., Koksal, G., Determination of optimal product styles by ordinal logistic regression versus conjoint analysis for kitchen faucets, Int J Ind Ergon, 2009, 39, 866-875, https://doi.org/10.1016/j. ergon.2009.06.007.

(C) 2018 by the author(s). Published by INCDTPICPI, Bucharest, RO. This is an open access article distributed under the terms and conditions of the Creative Commons Attribution license (http:// creativecommons.org/licenses/by/4.0/). 